\title{
MAFFESOLI, Michel. A parte do diabo. Trad. Clóvis Marques. Rio de Janeiro: Record, 2004.
}

\author{
Julio Cesar Jeha \\ Universidade Federal de Minas Gerais
}

$\mu$

tradução de La Part du diable (Flammarion, 2002) traz para o leitor brasileiro o trabalho de Michel Maffesoli sobre o mal na cultura contemporânea. Maffesoli é sociólogo, co-fundador do Centre d'études sur l'actuel et le quotidien (Sorbonne/Paris V), e vice-presidente do Institut International de Sociologie.

Grosso modo, filósofos e teólogos discutem o problema do mal, que se resume a esta pergunta: se Deus é bom e onipotente, então como pode permitir o mal? Ao contrário deles, os sociólogos buscam explicar os processos pelos quais o mal se faz presente nas sociedades. Maffesoli se concentra em fenômenos contemporâneos como as raves e os pegas de carro, que seriam os sintomas mais aparentes da violência urbana, cada vez mais forte e incontrolável.
Maffesoli dividiu A parte do diabo em prólogo mais cinco capítulos. Na parte inicial, apresenta o tema do livro: confunde-se fazer o bem com extinguir o mal e disso resultam os piores crimes. É preciso, diz o autor, aceitar a complexidade da natureza, o relativismo cultural e o tribalismo emocional. Em vez de tentar acabar com o mal, devese acolhê-lo como parte integrante do mundo. Os demais capítulos desenvolvem essas idéias, sempre associando a exclusão do bem com um suposto espírito prometéico, característico da modernidade, que agora estaria dando lugar ao dionisíaco, típico da pós-modernidade.

No capítulo intitulado "Pequena epistemologia do mal", Maffesoli trata do espírito animal e da energia dos sentimentos. Segundo ele, não há como negar que o mal nos persegue sob diferentes formas: "agressividade, 
violência, sofrimento, disfunção [e] pecado" (p. 27). No entanto, a cultura ocidental se recusa a aceitálo como parte da natureza humana, como a sombra junguiana, e tenta eliminá-lo, o que serve apenas para fazê-lo retornar com maior ímpeto, com conseqüências cada vez mais danosas. Melhor seria tomá-lo como "também" um elemento do mundo. Para tanto, faz-se necessária uma metodologia, ou melhor, uma epistemologia que enfatize "o paroxismo, a caricatura, a forma como capacidade de pôr em palavras o que é vivido" (p. 28). Tal abordagem permitiria analisar o conflito entre vida e morte, entre nossos afetos e nossa razão; permitiria, enfim, encarar "a volta do mal [à] ordem do dia”, aproximando-nos de um "espirito natural" (p. 29). Esse espírito é uma tensão que sempre se renova, sem jamais se resolver "numa síntese ou em outras formas de uniformidade ou universalismo" (p. 31-32). Afas-tamo-nos, assim, do Iluminismo e do primado da cientificidade, em direção ao pós-modernismo e sua predileção por uma "sabedoria demoníaca" (p. 32), mais vivida que pensada; relativista, sincrética, holística, alternativa; em suma, um movimento rumo à New Age.

A cultura pós-moderna, diz Maffesoli, nega a transcendência a condição essencial ao Deus cristão
- em favor da imanência, considerando ambos o mal e o divino como parte da natureza humana. No hiato da modernidade, nossa parte animal teria sido reprimida, apenas para retornar agora com mais vigor, evidenciada pelo culto ao corpo e à sua transformação. Em oposição à energia visando a dominar, baseada no conhecimento, característica do projeto iluminista e modernista, na pós-modernidade, teríamos uma libido visando a sentir, animada pelos sentidos, pelo prazer relativo ao presente e ao local. Melhor dizendo, no pósmodernismo a "transcendência se imanentiza" (p. 49). Ora, essa característica, somada ao paradoxo, ao jogo dos contrários, aponta para o ressurgimento do barroco como estilo de arte e de vida, no qual prevalece um holismo fundamental, arcaico e tradicional.

O conflito estrutural, título do segundo capítulo, se refere à existência do bem e do mal no mundo, um binarismo onipresente que se traduz em amor-ódio, atraçãorepulsão, generosidade-egoísmo, ou ainda, apolíneo-dionisíaco (p. 62). Esse dualismo incontornável traz à luz o outro, o estrangeiro, o recalcado, o negado. Com isso, rui o "totalitarismo ontológico", isto é, Deus, Ser, perfeição, que, a bem da verdade, nunca teria conseguido se sustentar por muito tempo (p. 63). 
O corte, a separação entre luz e trevas, proveniente de uma libido da cisão, e um ato fundador da cultura ocidental, é um artifício intelectual, ao passo que a coincidência dos opostos é integradora, animada pela libido do sentir. Porém, integrar não é fazer um clone de si: aceitar o estrangeiro é "admitir que sua diferença tenha um efeito sobre a sociedade, que a alteridade perdure" (p. 65). E a alteridade máxima se apresenta sob a forma da morte, o contrário da vida, seu limite que lhe dá existência. Assim, se a vida é plenitude, a morte é vazio, mistério tremendo e sublime, cuja força nos atrai.

Paralela à atração do vazio está a força do mal, que tampouco se pode refutar. Origina-se daí, como nos lembra Maffesoli, o problema com que se deparam inúmeras religiões e sistemas filosóficos: como explicar a existência do mal num universo criado por uma divindade benevolente e todopoderosa? "Eis então o escândalo essencial, aquilo que explica a denegação ou o recalque da realidade do mal" (p. 77). Reconhecê-lo implicaria enfraquecer a deidade e suas hipóstases, quer sejam elas o Estado, as Igrejas, ou as instituições sociais. Daí a necessidade de se trazer à cena um subalterno, responsável por esse estado de coisas.

No cristianismo, esse papel de sujeito dependente coube a
Satã, entidade alheia às religiões gregas e romanas, manifestações politeístas que acolhiam todas as divindades em seus panteões, mesmo as estrangeiras e as ainda desconhecidas. Satã foi exilado para as profundezas, onde uma escuridão visível, no dizer de Milton, oculta sua culpa pelo mal no mundo. Reconhecer sua existência, portanto, é falar de nós mesmos, desse nosso lado renegado, e assim, "reconciliarse com a alteridade" (p. 82). Tratase, na pós-modernidade, não de confessar o lado oculto e extirpá-lo, freudianamente, mas de aceitá-lo, à maneira de Jung, como parte integral da comunidade em que vivemos. Ao torná-lo comum e incorporá-lo a rituais, nós o suportamos mais facilmente.

Os três capítulos finais, "Variações sobre a sombra", "Inteireza do ser" e "Transmutação do mal", tornam mais explícita a opção de Maffesoli por Jung. Em "Variações ...", o autor continua a celebrar a "duplicidade antropológica" como um "modo operatório de sobrevivência" (p. 93) no mundo contemporâneo. Para ele, devemos abandonar a História, o Indivíduo e o Iluminismo, por serem parte do projeto judaico-cristão, que transformou o bem e o mal em valores absolutos e racionais, com as desastrosas conseqüências da Modernidade. Devemos adotar a 
composição, a pessoa e a New Age, traduzidas pelo sincretismo religioso, que, ao enfatizar o relativo, considera o bem e o mal entidades fraternas, convivendo numa tensão dinâmica.

A inteireza do ser, proposta por Maffesoli no quarto capítulo, implica aceitar o indivíduo como um ser fragmentado, pleno de inquietude, dilacerado por um conflito interno. Essa tensão entre o eu e o outro dentro de mim (o daimon platônico) mantém as culturas vivas, criativas e sempre em mutação. De maneira similar, o homem moderno colide com a sabedoria popular; aquele se guiando por uma moral excludente e esta, por uma ética abrangente. O pósmodernismo, segundo o sociólogo francês, tende para uma "rearcaização", um "reencantamento" do mundo, num movimento de "holismo tribal" (p. 121-123). Nessa perspectiva, a morte aparece como um duplo da vida, tal como reconhece o pós-modernismo e como o modernismo teria rejeitado. Para este, a morte é desprovida de lógica, portanto, deve ser superada; para aquele, ela faz parte da economia geral do dia-a-dia, "que permite viver o excesso, o mal, a desordem" (p. 130). Aceitar isso é restaurar o equilíbrio natural.

O livro termina com "Transmutação do mal", no qual o autor reitera sua proposta de integrarmos o mal à vida, aceitando-o como parte indissolúvel da nossa realidade. Essa fusão levaria ao êxtase, experimentado tanto pelos religiosos quanto pelos jovens participantes das raves ao descobrirem o vazio do ser. Aparece aqui o arquétipo do continente: em vez do logos, pleno de significado, o loco, o mundo como um vazio, propício ao crescimento do ser (p. 176). É a essa "cripta social" que nos voltamos em busca de energia criadora. Tornar-se consciente desse fato e aceitá-lo equivale a adotar a "sabedoria da noite", o saber do matriarcado, inclusivo, solidário, indulgente, em vez da razão patriarcal, julgadora, discriminatória e excludente. Para Maffesoli, a sociedade pós-moderna está efetuando essa transmutação, substituindo Prometeu por Dionísio, permitindo que a flor se reconheça no mal de onde saiu (p. 187).

Maffesoli faz de $A$ parte do Diabo um manifesto da New Age, a favor da inclusão de tudo e todos, como se fossem um dado da realidade. Vai contra a modernidade e o que ela representa, por tentar impor, segundo ele, o totalitarismo da ontologia, isto é, do Ser absoluto, em detrimento do relativismo da ontogênese, instaurado pelo pósmodernismo. Ao fazer isso, o autor adere à tribo dos anti-racionalistas, 
denunciando a razão e o Iluminismo como culpados das mazelas que acometeram a humanidade nos últimos séculos. Tal acusação não pode ser feita sem alguns reparos.

Ainda que o sociólogo francês tente se precaver de críticas ao seu método, reconhecendo os paradoxos que apresenta, seu mea culpa não explica nem redime as várias contradições encontradas no livro. De início, ele acusa a modernidade e o Ocidente de serem totalitários e excludentes, de erigirem um altar ao Eu e banirem o Outro, numa estratégia binária. No entanto, é exatamente essa a tática adotada por Maffesoli ao correr do livro: joga Dionísio contra Prometeu, Jung contra Freud, modernidade contra pós-modernidade, razão contra emoção; enfim, comete o binarismo que ele aponta como a raiz de todos os males. E mais: ele dirige seu livro "aos espíritos esclarecidos" (p. 27), isto é, àqueles poucos iluminados capazes de entender que bem e mal fazem parte do mundo e da vida.

Coerente em sua contradição, Maffesoli defende a teoria pendular da história, adotada por, entre outros, Légouis e Cazamian em sua História da Literatura Inglesa, há muito desacreditada pelos fatos. Segundo o autor francês, tudo o que vai volta. Em sucessão ao modernismo teremos de novo o barroco, transfigurado em pósmodernismo e sua aceitação do mal como um dado mundano. Isso seria comprovado pela anomia flagrante na Europa, com os jovens abstendose de votar e vaiando os símbolos nacionais. A juventude, segundo ele, estaria se reunindo em raves para ouvir música techno, de ritmo marcado e tocada em alto volume, para celebrar o coletivo e retornar ao arcaico, à natureza, ao animal dentro do humano. Propor que isso caracterize uma suposta pósmodernidade é jogar no lixo os anos 60, com os concertos de Woodstock e Altamont, os Rolling Stones e Janis Joplin, o movimento hippie, as demonstrações contra a Guerra do Vietnam, a luta pelos direitos civis.

Apontar o dedo para a tradição judaico-cristã e incriminá-la por tentar separar o mal do bem, como se ambos fossem incompatíveis, é escamotear parte da história. Em Isaías 45:7, por exemplo, o profeta descreve o plano de Deus: "Eu formo a luz e crio as trevas; eu faço a paz e crio o mal; eu, o Senhor, faço todas essas coisas". Ainda que teólogos e filósofos venham, há milênios, tentando explicar a coexistência de uma divindade benevolente e o mal num mesmo universo, eles jamais tiveram sucesso. Essa separação faz parte de várias religiões, não apenas do cristianis- 
mo. Veja-se, por exemplo, a atitude dos terroristas muçulmanos, repetida em carta após o ataque de 11 de março em Madri: "Vocês adoram a vida; nós desejamos a morte". Tal oposição entre Eu e Outro, nacional e estrangeiro, bem e mal, vai além de uma divisão geopolítica entre Ocidente e Oriente: ela fundamenta o aspecto mais primitivo da natureza humana.

A parte do diabo, que traz na capa o subtítulo "Resumo da subversão pós-moderna”, é um livro com validade vencida, que enterra umas poucas boas idéias nos escombros de um pensamento ultrapassado. Melhor teria feito a Editora Record se houvesse traduzido o recém-publicado Les temps hypermodernes, do também francês Gilles Lipovetsky, que denuncia a falácia do pós-moderno, arrependido de ter ajudado a popularizar a noção de que tal período tivesse existido. Resta ao leitor brasileiro aguardar sua tradução e verificar como suas idéias se comportam no teste inexorável do tempo. 